\title{
Perancangan Sistem Informasi Pemasaran dan Penjualan Lukisan pada Polesan Art Galeri
}

\author{
Ramdani Quraisshihab $^{1}$, Yusmal Handiyana ${ }^{2}$, Dyland Agustian ${ }^{3}$ \\ Sistem Informasi, Fakultas Teknik dan Ilmu Komputer, Universitas Komputer Indoensia, Bandung, Indonesia \\ ramdaniquraisshihab@mahasiswa.unikom.ac.id
}

Diterima 17 Mei 2019

Disetujui 24 Juni 2019

\begin{abstract}
This research was conducted to design a webbased painting sales information system design in an art gallery. The research method used in this study uses descriptive methods, namely by explaining the phenomena that occur from data collected through observation and interviews. And using a structured approach method and for system development using the waterfall method. The results of this study are websitebased painting sales application designs in art galleries. Currently the painting marketing process is still limited to certain areas, which makes it difficult to increase the sales volume of paintings when tourists visit a little, and consumers are required to come directly to the gallery to make transactions so consumers who don't have time to buy paintings in art galleries. Thus to improve the marketing process and make it easier for consumers to buy paintings anytime and anywhere, then design webbased marketing and sales information systems. The design of this marketing and sales information system aims to improve marketing by disseminating information about products to be sold and providing services to consumers to make purchases that can be done anywhere and ultimately will provide maximum service which will ultimately increase revenue from art galleries. polished.
\end{abstract}

Index Terms-enter Sales, Information Galleries, Website.

\section{PENDAHULUAN}

Pemasaran dapat di definisikan sebagai suatu produk berupa barang atau jasa untuk dapat di ketahui, dimengerti, dipahami, dan disukai oleh masyarakat atau konsumen perlu di pasarkan [1]. Pemasaran juga dapat di artikan sebagai bagian dari sebuah promosi dimana promosi adalah sebagian dari keseluruhan dari proses pemasaran [2]. Pemasaran dan penjualan mempunyai tujuan untuk mengenalkan produk secara luas untuk menarik banyak konsumen sehingga mampu meningkatkan penjualan suatu produk sehingga sebuah perusahaan akan menghasilkan pendapatan.

Penelitian sebelumnya yang di lakukan oleh Rizal mutaqin menghasilkan sebuah sistem informasi penjualan lukisan berbasis web di sanggar seni lukis Robert frame, sistem yang di rancang adalah sistem yang mampu melakukan pemasaran lukisan secara luas serta mampu melakukan pengolahan data dan mendistribusikan informasi kepada konsumen secara cepat dan akurat [3].

Dengan perkembangan teknologi informasi di zaman yang modern ini tentunya akan memberikan kemudahan dan keuntungan, tak terkecuali pada bidang bisnis Dengan di terapkannya internet dan teknologi informasi proses pemasaran dan penjualan suatu produk dapat di lakukan kapanpun dan dimanapun [4]. Sehingga proses pemasaran produk akan tersebar lebih luas dan proses pembelian produk dapat dilakukan dimana saja dan akhirnya akan memberikan pelayanan yang maksimal yang pada akhirnya akan meningkatan pendapatan dari perusahaan itu sendiri.

\section{PENELITIAN TERDAHULU}

Penelitian sebelumnya yang dilakukan Iyan Gustiana. Dengan melakukan perancangan sistem informasi penjualan on line pada pt. ochikawa headwears project[11]. Penelitian selanjutnya yang dilakuakn oleh Tono Hartono, S.Si, MT dengan melakukan perancanagan perangkat lunak pendukung penjualan dan pembelian pakaian jadi pada toko "xyz" [5]. Penelitian selanjutnya yang dilakuakn oleh Sandy Kosasi dengan melakukan penelitian pembuatan sistem informasi penjualan berbasis web untuk memperluas pangsa pasar [6].penelitian selanjutnya yang di lakukan oleh Edwin Sugesti dengan melakukan pengaruh sistem informasi pemasaran dan strategi penjualan terhadap persaingan penjualan produk pt. bank agris, tbk medan[7]penelitian selanjutnya yang di lakukan oleh Fery Setyaningrum dengan melakukan seni lukis sokaraja: proses pewarisan dan pemasarannya dalam konteks pasar seni[8] penelitian selanjutnya yang di lakukan oleh I Nyoman Yoga Setyawan, Ni Wayan Marti dengan membuat sistem informasi kerajinan lukisan kaca desa nagasepaha berbasis web[10]

\section{Metode PENELITIAN}

Penelitian dilakukan di polesan art galeri bandung yang bertempat di Jl Asia Afika No 5. Bandung. Penelitian di lakukan pada tanggal 27 April 2019. Metode pendekatan yang di gunakan dalam penelitian ini adalah terstruktur dan pengembangan sistem menggunakan metode waterfall Pressman. Rogers, 
yaitu meliputi 5 tahapan : Requirement, Design, Implementation, Verification, Maintenance [9].

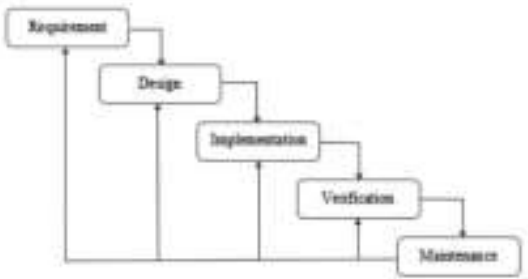

Gambar 1. Model Waterfall (Sumber : Rekayasa Perangkat Lunak - Buku Satu, Pendekatan Praktisi [9] )

\section{- Requirement}

langkah ini seorang pengembang di haruskan melakukan komunikasi dengan bagian dari perusahaan untuk mampu memahami sistem yang di inginkan oleh pengguna dan batasan sistem tersebut [9]. Informasi ini di dapatkan dengan melakukan wawancara kepada bagian yang terlibat dalam penggunaan sistem ini dan melakukan observasi dengan mengamati proses pemasaran dan penjualan pada polesan art galeri.

\section{- Design}

Spesifikasi yang di butuhkan pada tahap spesifikasi yang di butuhkan pada tahap pertama akan di kaji dalam tahap ini serta menyiapkan sebuah desain sistem. Untuk membantu dalam memilih pirantikeras dan persyaratan sistem untuk menolong dalam menjelaskan arsitrktur keseluruhan sistem [9].

\section{- Implementation}

Tahap selanjutnya, sistem akan di kembangkan pada program kecil yang disebut unit, yang saling berhubungan dalam tahap yang akan di lakukan setelah tahap ini. [9].

\section{- Verification}

Semua unit yang dikembangkan dalam pada implementasi di hubungkan ke dalam sistem setelah pengujian yang dilakukan pada setiap unit. Setelah integrasi terhadap setiap unit dan diuji untuk mengetahui setiap kegagalan dan kesalahan [9]. Pengujian yang di lakukan pada sistem informasi pemasaran dan penjualan adalah menggunakan pengujian black box testing.

\section{- Maintenance}

Langkah terakhir. Piranti lunak yang telah selesai di buat, digunakan serta di pelihara. Pemeliharaan dapat di katakan sebagai cara memperbaiki kesalahan yang tidak ditemukan pada langkah sebelumnya. Perbaikan implementasi unit sistem dan peningkatan jasa sistem sebagai kebutuhan baru [9].

\section{HASIL DAN PEMBAHASAN}

\section{A.1 Analisis Sistem yang Berjalan}

Berikut ini adalah perancangan dan pembangunan sistem pada sistem pemasaran dan penjualan pada polesan art galeri :

\section{A.1.1 Analisis Sistem yang Berjalan}

Berikut ini adalah analisis sistem pemasaran dan penjualan yang berjalan pada polesan art galeri :

- Analisis prosedur yang berjalan :

1. Konsumen mendatangi galeri.

2. Konsumen memilih lukisan yang di pajang.

3. Konsumen menyerahkan data lukisan kepada penjual.

4. Pegawai mengambil lukisan untuk segera di proses.

5. Konsumen melakukan pembayaran.

6. Kemudian Penjual membuat bukti pembayaran berupa nota.

\section{A.1.2 Perancangan yang Diusulkan}

Berikut ini adlah perancangan sistem yang di usulkan pada sistem pemasaran dan penjualan pada polesan art galeri :

Prosedur yang di usulkan :

Berdasarkan analisis terhadap sistem penjualan yang sedang berjalan pada polesan art galeri, berikut ini adalah prosedur yang di usulakan pada polesan art galeri :

Prosedur yang dapat di lakukan administrator web:

1. Tambah, edit, hapus data kategori lukisan

2. Tambah, edit, hapus data pemasok lukisan

3. Tambah, edit, hapus data data lukisan

4. Tambah, edit, hapus, konfirmasi pemesanan

5. Membalas pesan masuk dari konsumen

6. Membuat Laporan

- Prosedur Penjualan Lukisan yang di usulkan :

1. Calon konsumen mengunjungi website polesanart.

2. Untuk melakukan pembelian produk, konsumen di haruskan untuk melakukan registrasi dan login.

3. Jika calon konsumen akan melakukan pembelian produk, calon konsumen bisa 
langsung memilih produk yang di tampilkan pada halaman utama.

4. Jika calon konsumen telah menemukan produk yang akan di beli, konsumen tinggal memilih tombol details, yang akan di arahkan pada sebuah form pemesanan dimana konsumen dapat menentukan jumlah lukisan yang akan di beli.

5. Tekan tombol buy now untuk menyipan pesanan tersebut di keranjang.

6. Jika calon konsumen ingin melanjutkan lagi, konsumen dapat memilih tombol continue shopping dan akan di alihkan kembali pada menu utama.

7. Jika pesanan sudah selesai, konsumen tinggal menekan tombol checkout dan kan di arahkan pada menu pembayaran.

8. Konsumen dapat memilih metode pembayaran

9. Setelai selesai konsumen akan di berikan informasi pemesanan dan jumlah harga yang harus di bayarkan.

10. Admin akan memberikan informasi transfer dengan memberikan no rekening agar konsumen segera melakukan transfer.

11. Setelah transfer di terima, admin akan memproses pesanan tersebut dan memberikan informasi berupa konfirmasi pada halaman order, dimana konsumen akan megetahui bahwa pesanan telah di proses.

\section{A.1.3 Data dan Informasi}

Berikut ini adalah data dan informasi yang di usulkan pada sistem pemasaran dan penjualan pada polesan art galeri :

\section{a. Diagram Konteks}

Dari prosedur yang di usulakan dan telah di uraikan di atas, maka di buatlah gambaran aliran data menggunakan diagram konteks, berikut ini adalah diagram konteks pemasaran dan penjualan :

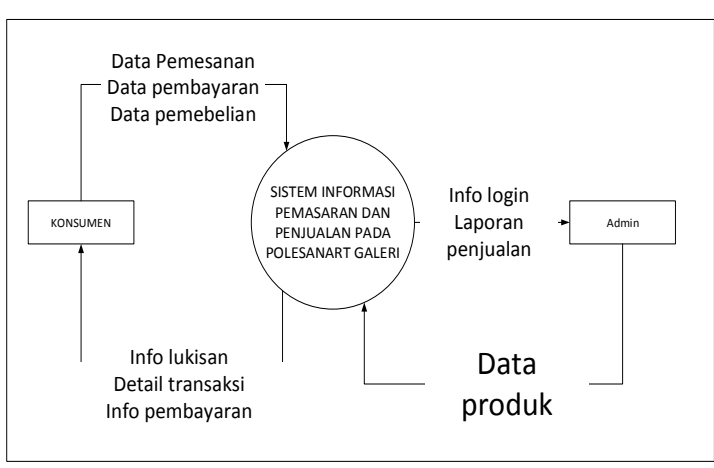

Keterangan :

Gambar 2. Diagram Konteks

- Sistem informasi pemasaran dan penjualan menerima input data konsumen,data pembayaran, data pembelian, dan data produk.

Sistem informasi pemasaran dan penjualan menampilkan output berupa info lukisan, detail transaksi, info pembayaran,info login dan laporan penjualan.

b. Data Flow Diagram

- Dfd Level 0

Berikut ini adalah dfd level 0 pada sistem informasi pemasaran dan penjualan lukisan :

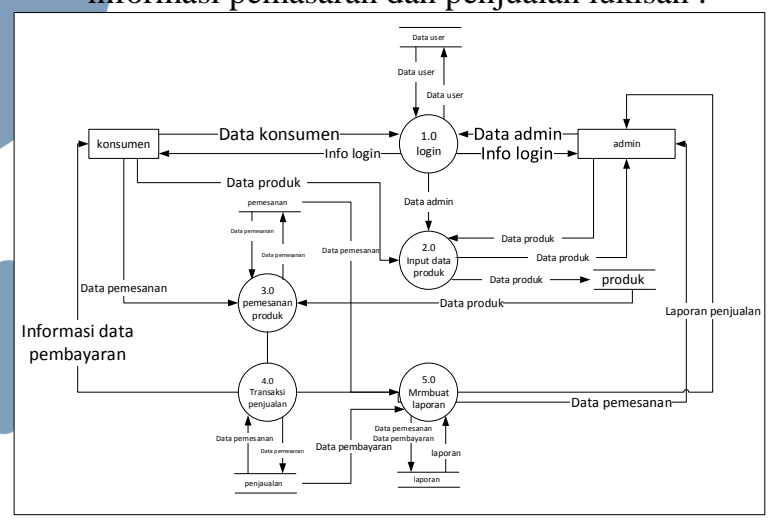

Gambar 3. DFD Level 0

Keterangan :

- Proses 1 user (admin dan konsumen) melakukan login.

- Proses 2 admin melakukan input data produk, dan data tersimpan pada database.

- Proses 3 lonsumen melakukan pembelian produk, produk di tampilkan dari data yang sebelum nya telah di input oleh admin.

- Proses 4 sistem memberikan informasi pembayaran kepada konsumen, agar konsumen segera melakukan pembayaran.

- Proses 5 admin membuat laporan berdasarkan data transaksi penjualan yang sudah ada.

- $\quad$ Dfd Level 1 Proses 1 
Berikut ini adalah dfd level 1 proses 1 pada sistem informasi pemasaran dan penjualan lukisan :

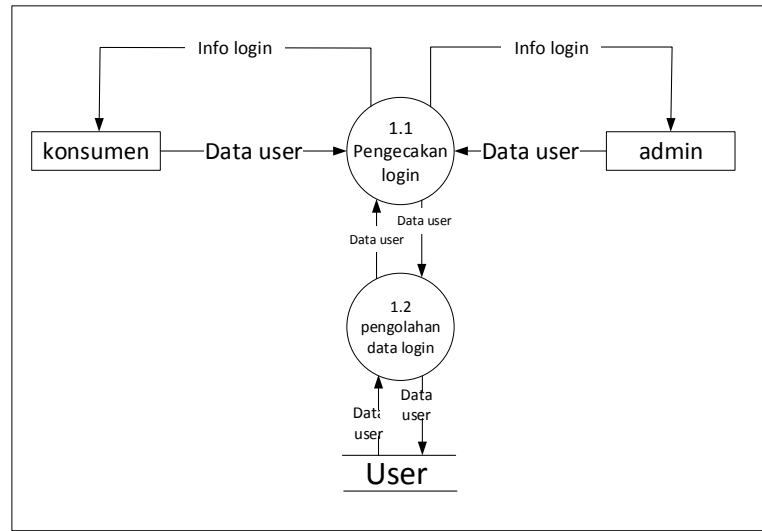

Gambar 4. DFD Level 1 Proses 1

Keterangan :

- Proses 1.1 user (admin dan konsumen) melakukan login dengan menginputkan data user dan sistem mengecek data user

- Proses 1.2 dari data yang telah di input dan di cek, sistem mengolah data user dengan lalu memberikan info login kepada user (konsumen,admin)

Dfd Level 2 Proses 3

Berikut ini adalah dfd level 2 proses 2 pada sistem informasi pemasaran dan penjualan lukisan :

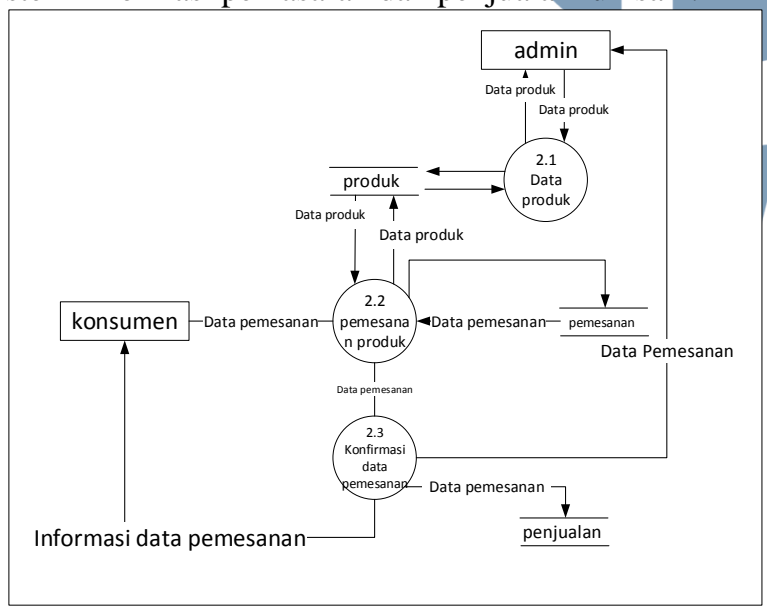

Gambar 5. Dfd level 2 proses 3

Keterangan :

- Proses 2.1 admin melakukan input data produk, lalu sistem menyimpannya.

- Proses 2.2 sistem menampilkan produk, dan konsume melakukan pemesanan,lalu sistem menyimpan data pemesanan

- $\quad$ Proses 2.3 sistem menampilkan informasi data pemesanan, lalu sistem menyimpan data tersebut sebagai data penjualan.

\section{A.1.4 Implementasi Basis Data}

Perancanagan database dilakukan dengan menggunakan bahasa SQL dan DBMS yang digunakan adalah MYSQL. Berikut ini adalah implementasi database sistem informasi pemasaran dan penjualan lukisan :

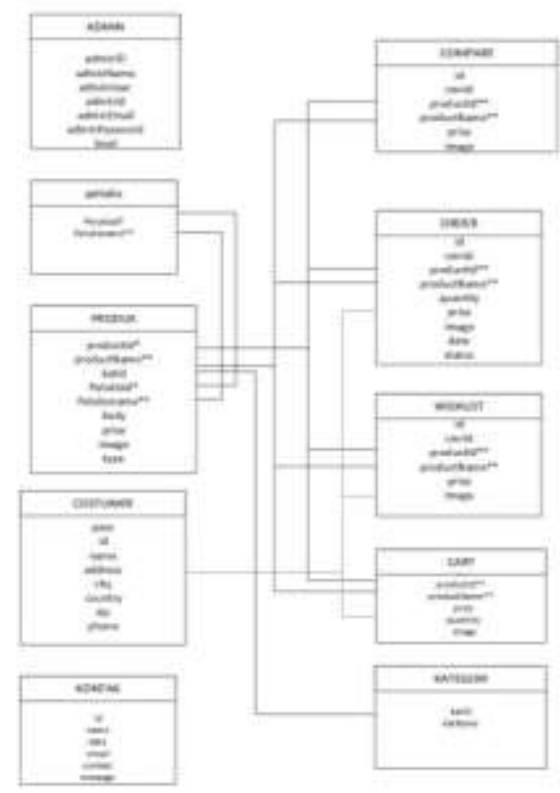

Keterangan :

* primary key

**foreign key

Gambar 6. Implemtasi Basis Data

\section{A.1.5 User Interface}

Untuk dapat mengakses halaman admin dan mengelola transakski penjualan admin di haruskan untuk login terlebih dahulu dengan menginputkan username dan password. Berikut ini adalah tampilan form login admin :

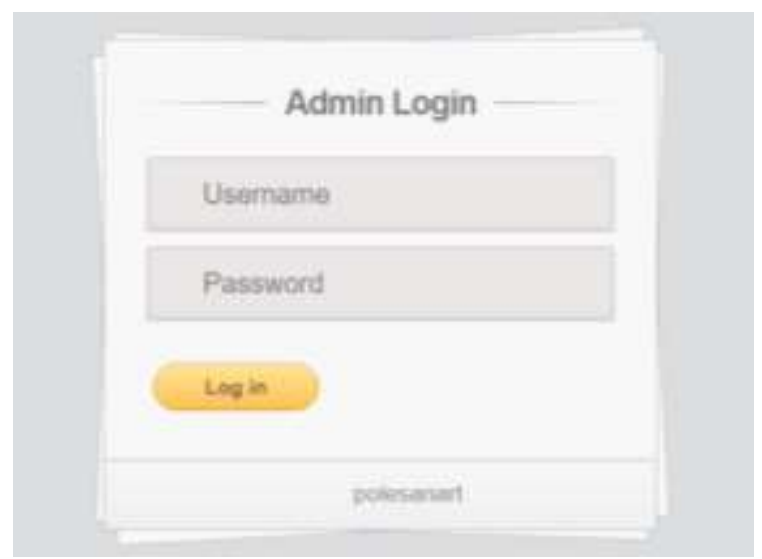

Gambar 7. Tampilan Form Login Admin

Setelah admin berhasil login, selanjutnya admin akan diarahkan pada tampilan dashboard, berikut adalah tampilan dashboard admin : 


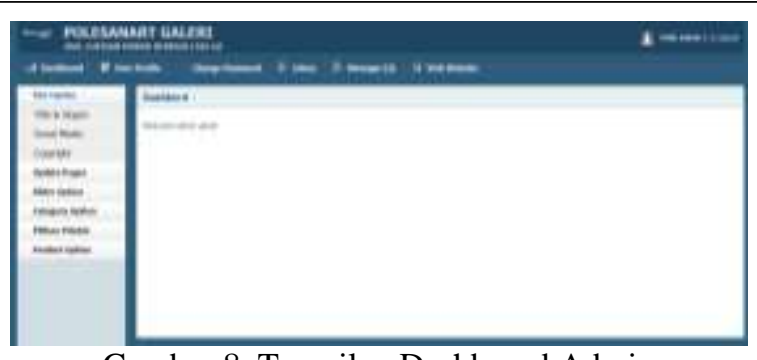

Gambar 8. Tampilan Dashboard Admin

Untuk mengolah data lukisan admin dapat memilih menu category options, untuk mengolah data pelukis admin dapat memilih menu painter options, untuk mengolah data produk admin dapat memilih menu product options, dan produk yang telah di pasarkan dapat di lihat pada menu post list seperti berikut ini :

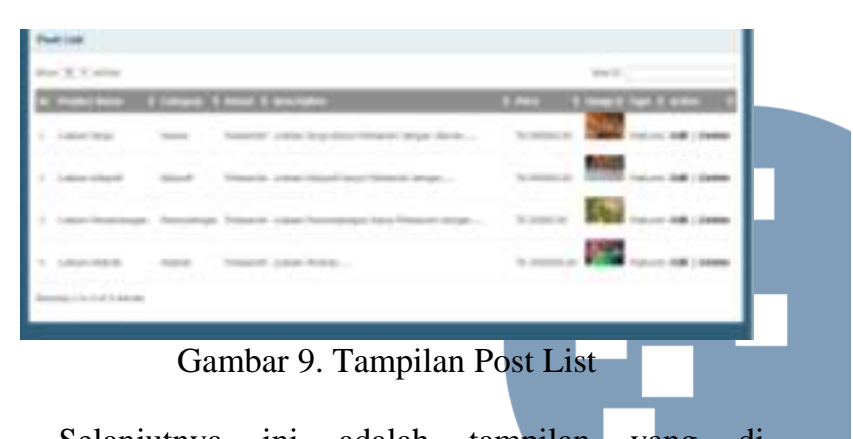

Selanjutnya ini adalah tampilan yang di peruntukan untuk konsumen dimana untuk dapat melakuakn transaksi, konsumen di haruskan untuk melakukan registrasi lalu login, berikut adalah halaman registrasi dan login :

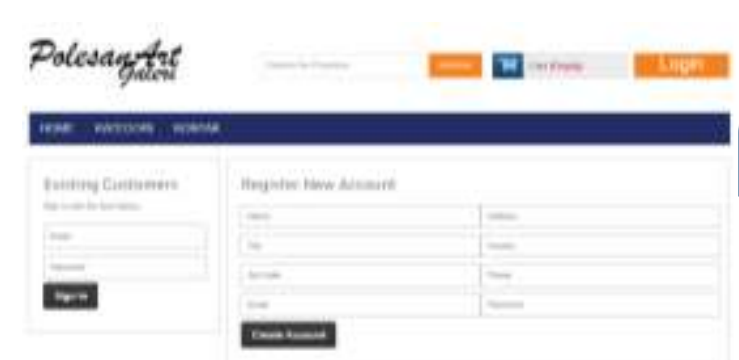

Gambar 10. Tampilan Login \& Daftar Konsumen

Setelah konsumen berhasil login, selanjutnya konsumen akan diarahkan pada tampilan tampilan utama website,dimanan pada halaman ini akan di tampilkan list produk dan konsumen dapat langsung memilih nya dengan menekan tombol beli, berikut adalah tampilan utama website $\&$ list produk :

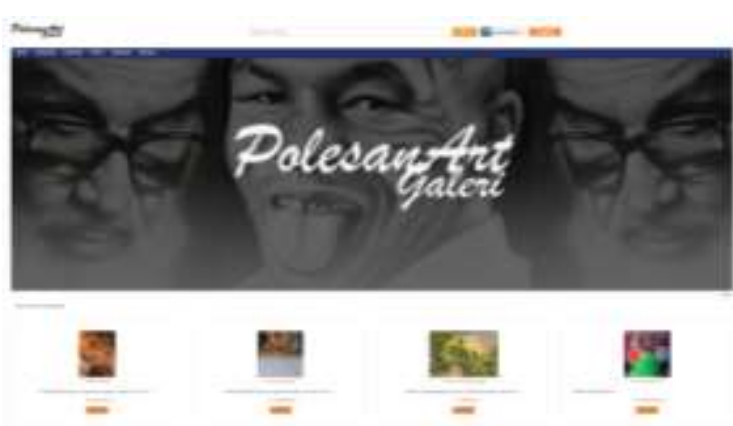

Gambar 11. Tampilan Halaman Utama

\section{A.1.5 Arsitektur Jaringan}

Berikut ini adalah perancangan arsitektur jaringan yang di usulkan pada polesan art galeri, arsitektur jaringan ini di buat menggunakan cisco packet tracer.

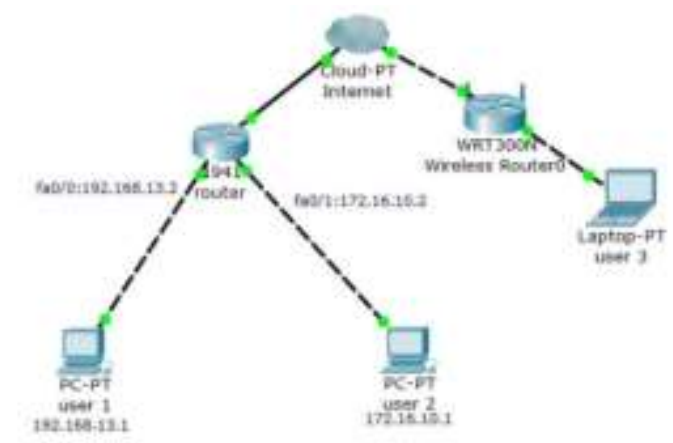

Gambar 12. Arsitektur Jaringan

A.1.5 Verification

Dalam proses verifikasi melalui pengujian sistem yang di uraikan pada tabel di bawah ini :

\begin{tabular}{|c|c|c|c|}
\hline \multicolumn{4}{|c|}{ Kasus dan Hasil Uji (Data Normal) } \\
\hline Data Inputan & Data Yang Benar & Pengamatan & Kesimpulan \\
\hline $\begin{array}{l}\text { username : } \\
\text { admin } 123 \\
\text { Password : } \\
\text { admin } 123\end{array}$ & $\begin{array}{l}\text { Menampilkan } \\
\text { Dashboard Admin }\end{array}$ & $\begin{array}{l}\text { dapat } \\
\text { masuk / } \\
\text { mengak } \\
\text { ses } \\
\text { halama } \\
\text { n } \\
\text { dashbo } \\
\text { ard } \\
\text { admin }\end{array}$ & $\begin{array}{l}\text { [X] Diterima } \\
\text { [ ] Ditolak }\end{array}$ \\
\hline $\begin{array}{l}\text { Tidak } \\
\text { menginut } \\
\text { data atau } \\
\text { salah } \\
\text { username } \\
\text { dan } \\
\text { pasword }\end{array}$ & $\begin{array}{l}\text { tidak bisa login } \\
\text { dan menyajikan } \\
\text { username atau } \\
\text { pasword anda } \\
\text { salah }\end{array}$ & $\begin{array}{l}\text { admin tidak } \\
\text { bisa } \\
\text { melakukan } \\
\text { login dan } \\
\text { memberikan } \\
\text { pesan untuk } \\
\text { "Input } \\
\text { Lagi" }\end{array}$ & $\begin{array}{l}\text { [ ] Diterima } \\
\text { [X] Ditolak }\end{array}$ \\
\hline
\end{tabular}


2. Login Konsumen

\begin{tabular}{|c|c|c|c|}
\hline \multicolumn{4}{|c|}{ Kasus dan Hasil Uji (Data Normal) } \\
\hline $\begin{array}{c}\text { Data } \\
\text { Masukan }\end{array}$ & $\begin{array}{c}\text { Data } \\
\text { diharapkan }\end{array}$ & Pengamatan & Kesimpulan \\
\hline $\begin{array}{c}\text { username : } \\
\text { ramdaniqs7 } \\
@ \text { gmail.co } \\
\text { m } \\
\text { Password : } \\
\text { Januari123 }\end{array}$ & $\begin{array}{l}\text { Menampilkan } \\
\text { menu utama } \\
\& \text { list Produk } \\
\text {, melakukan } \\
\text { pembelian } \\
\text { produj }\end{array}$ & $\begin{array}{l}\text { dapat masuk } \\
\text { / mengakses } \\
\text { halaman } \\
\text { utama \& list } \\
\text { Produk, } \\
\text { melakukan } \\
\text { transaksi } \\
\text { pembelian } \\
\text { produk }\end{array}$ & $\begin{array}{c}\text { [X] Diterima } \\
\text { [] Ditolak }\end{array}$ \\
\hline $\begin{array}{c}\text { Data } \\
\text { kosong } \\
\text { atau salah } \\
\text { username } \\
\text { dan } \\
\text { pasword } \\
\text { atau } \\
\text { username } \\
\text { tidak } \\
\text { mengikuti } \\
\text { format } \\
\text { yang } \\
\text { sudah di } \\
\text { tntukam }\end{array}$ & $\begin{array}{l}\text { tidak bisa } \\
\text { login dan } \\
\text { menyajikan } \\
\text { username } \\
\text { atau } \\
\text { pasword } \\
\text { anda salah }\end{array}$ & $\begin{array}{l}\text { Konsumen tidak } \\
\text { bisa login dan } \\
\text { menampilkan } \\
\text { pesan untuk } \\
\text { "login dengan } \\
\text { username \& } \\
\text { password yang } \\
\text { sesuai" }\end{array}$ & $\begin{array}{l}\text { [ ] Diterima } \\
{[\mathrm{X}] \text { Ditolak }}\end{array}$ \\
\hline
\end{tabular}

Perangkat keras yang digunakan berdasarkan kebutuhan minimal yang harus terpenuhi untuk menjalankan program tersebut antara lain adalah :

- Desktop

1. Processor Intel Core I3

2. Hardisk $500 \mathrm{~Gb}$

3. RAM 2GB

4. VGA 64 BIT

- Mobile

1. Processor with $1.3 \mathrm{GHZ}$ Quad Core CPU

2. OS Android 5 Lillipop

3. $1 \mathrm{~GB}$ RAM +8 GB ROM

\section{A.1.6 Analisis Dampak dan Manfaat}

Analisis terhadap dampak dan manfaat dengan di terapkannya sistem informasi pemasaran dan pemesanan pada polesan art galeri adalah sebagai berikut :

\section{Dampak}

Dengan di terapkannya sistem informasi ini tentu nya akan memberikan beberapa dampak positif bagi perusahaan, di antaranya :

- Proses pemasaran yang luas dan tidak terbatas pada satu wilayah tertentu

- Meningkatnya volume penjualan lukisan.

- Peluang bertambahnya konsumen semakin besar.
2. Manfaat

Dengan di terapkannya sistem informasi ini tentu nya akan memberikan beberapa manfaat bagi perusahaan, di antaranya :

- Mempermudah pegawai (admin) untuk mengolah transaksi penjualan yang terjadi

- Mempermudah proses penyajian data lukisan dan penjualan

- Memberikan kemudahan bagi konsumen untuk melakukan transaksi dimana saja.

\section{SimpUlan}

Perancangan sistem informasi pemasaran dan penjulan pada Polesanart galeri Bandung dapat terselaikan, meskipun masih banayak kekurangan dan harus di kembangkan lagi. Rancangan sistem informasi ini di harapkan dapat membantu :

- Memperluas proses pemasaran produk

Memungkinkan untuk konsumen dalam melalukan transaski dimanapun dan kapanpun.

Adapun saran yang dapat dikemukakan sebagai bahan pertimbangan bagi penelitian delanjutnya adalah sebagai berikut :

- Menyediakan metode pembayaran online untuk mempermudah proses pembayaran

Menyediakan akses untuk konsumen dapat melacak keberadaan kiriman yang telah di belinya..

\section{UCAPAN TERIMA KASIH}

Karya tulis ilmiah ini dapat terselesaikan oleh bantuan dari beberapa pihak, maka dari itu di sini penulis ingin mengucapkan terimakasih sebesarbesarnya kepada :

1. Leonardi Paris Hasugian, S.Kom, M. Kom, M.Eng. sebagai dosen pembimbing yang telah membantu untuk membimbing dalam pembuatan karya tulis ilmiah ini.

2. M Risal Ramdhani, Yusmal Handiyana, Gilang Maulana, Dyland Agustian sebagai teman satu kelompok dalam pembuatan karya tulis ilmiah ini.

\section{DAFTAR PUSTAKA}

[1]. Soegoto, E. S. "Entrepreneurship Menjadi Pebisnis Ulung" Edisi Revisi. Elex Media Komputindo, 162. 2014.

[2]. Abdullah, Thamrin dan Francis Tantri. Manajemen Pemasaran. Depok : PT Raja Grafindo Persada. 2016.

[3]. Rizal, Mutaqin . "Perancangan Sistem Infromasi Penjualan Lukisan Berbasis Web Pada Sanggar Seni Lukis Robert Frame", UNIKOM, 2013. 


\section{ISSN 2085-4579}

[4]. 4Jauhari, J. "Upaya pengembangan usaha kecil dan menengah (UKM) dengan memanfaatkan e-commerce". Jurnal Sistem Informasi, 2(1), 2014.

[5]. Tono Hartono, S.Si, MT PERANGKAT LUNAK PENDUKUNG PENJUALAN DAN PEMBELIAN PAKAIAN JADI PADA TOKO "XYZ" JAMIKA: Jurnal Ilmiah Manajemen Informatika Unikom 21 Apr 2014

[6]. Sandy Kosasi pembuatan sistem informasi penjualan berbasis web untuk memperluas pangsa pasar Prosiding Snatif, 2014

[7]. Edwin Sugesti pengaruh sistem informasi pemasaran dan strategi penjualan terhadap persaingan penjualan produk pt. bank agris, tbk medan JRMB (Jurnal Riset Manajemen dan Bisnis) 2018
[8]. Fery Setyaningrum seni lukis sokaraja: proses pewarisan dan pemasarannya dalam konteks pasar seni Imaji: Jurnal Seni dan Pendidikan Seni 2016

[9]. Pressman, Roger S. Rekayasa Perangkat Lunak - Buku Satu, Pendekatan Praktisi (Edisi 7) Andi. Yogyakarta.2012.

[10]. I Nyoman Yoga Setyawan, Ni Wayan Marti sistem informasi kerajinan lukisan kaca desa nagasepaha berbasis web NW Marti - Jurnal Pendidikan Teknologi 2013

[11]. Iyan Gustiana. PERANCANGAN SISTEM INFORMASI PENJUALAN ON LINE PADA PT. OCHIKAWA HEADWEARS PROJECT. JATI : Jurnal Teknologi dan Informasi UNIKOM. Volume 032013.

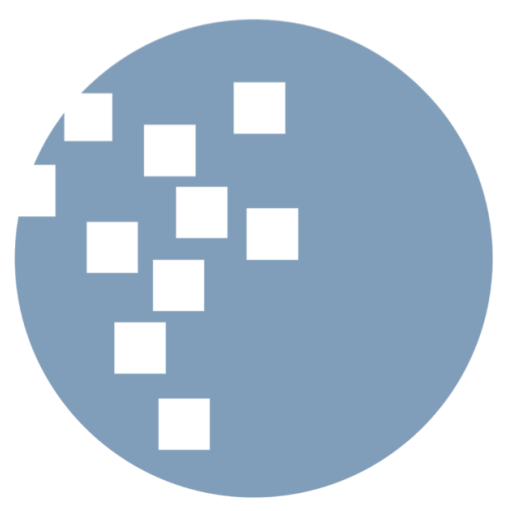

